\title{
Production Performances of Lactating Murrah Buffaloes Supplemented with Soybean Oil
}

\author{
Aayush Yadav*, G.P. Lakhani, Biswajit Roy, Bhavna Aharwal, \\ Sudipta Ghosh and R.P.S. Baghel \\ Department of Livestock Production and Management, College of Veterinary Science and \\ Animal Husbandry, NDVSU, Jabalpur, M.P., India \\ *Corresponding author
}

\section{Keywords}

Murrah, Soybean oil, Milk yield, Milk fat, $6 \%$ FCM

Article Info

Accepted:

24 September 2018

Available Online:

10 October 2018

\section{A B S T R A C T}

Twelve advance pregnant Murrah buffaloes of identical parity and similar previous lactation yield were selected 21 days pre-partum and randomly assigned to two groups of six animals each; CON as control with basal diet and SBO as soybean oil supplementation @ $200 \mathrm{ml} / \mathrm{animal} / \mathrm{day}$ upto 90 days post-partum to study the effect on production performances in lactating Murrah buffaloes at livestock farm, Adhartal, N.D.V.S.U., Jabalpur (M.P.). The BCS was evaluated using visual observation and palpation to 5 point scale and the milk components was analysed using ultrasonic auto milk analyser. The BCS, body weight, DMI, peak milk yield and persistency of lactation during entire study were statistically similar in both the groups. Results revealed significant $(\mathrm{p}<0.05)$ improvement in average daily milk yield by 13.54 per cent in SBO as compared to CON. The $6 \%$ FCM yield and predicted lactation yield were significantly $(\mathrm{p}<0.05)$ higher in SBO as compared to CON. The average milk fat content has significantly $(\mathrm{p}<0.05)$ improved by 7.25 per cent in SBO as compared to CON while SNF, protein and lactose per cent were statistically similar in both the groups. It can be concluded that SBO improved production performances in lactating Murrah buffaloes.

\section{Introduction}

Most of the animals in developing countries including India suffer shortage of feed resources and are fed on agriculture byproducts and low quality crop residues, which have got low nutritive value and digestibility, therefore resulting in low productivity of dairy animals. High producing dairy animals in early lactation lack sufficient dry matter to support maximal production of milk and thus, exhibit negative energy balance (NEB) for first 8 to 12 weeks. Their energy intake becomes inadequate to meet the energy requirements for maintenance and milk production from dietary sources. Under these conditions, animals usually have to draw upon their own body reserves to support the large volume of milk production, resulting into metabolic disorders, weight loss and fertility problems.

In this context, maximizing energy intake by increasing the energy density of diet is suited 
as a logical feeding strategy for early lactating dairy animals. Cereal grains and fats play a valuable role as sources of energy in the ration of dairy animals. As cereals are utilized for human consumption and monogastric animals and their excessive feeding to dairy animals give rise to rapid fermentation that leads to suboptimal rumen environment, acidosis and decline in the concentration of milk fat. Therefore, supplementing fat in the diets has become a standard practice to fulfil the energy requirements of dairy cows.

Dietary fat as tallow (Maiga et al., 1995), calcium salts of fatty acids (Sultana et al., 2008), mustard oil (Kathirvelan and Tyagi, 2009), soybean oil (Thakur and Shelke, 2010) and sunflower oil (Dai et al., 2011) in the ration of early lactating dairy animals has often increased milk production due to increase in energy intake and improved efficiency of energy utilization (Maiga and Schingoethe, 1997). Among these oils, soybean oil is cheapest source of fat supplements for dairy animals and is used traditionally in field conditions. Keeping the above facts in mind, the present experiment was designed to study the effect of supplementation of soybean oil on production performances in lactating Murrah buffaloes.

\section{Materials and Methods}

\section{Proposed work}

The proposed work was conducted on twelve advance pregnant Murrah buffaloes for a period of six months at Livestock Farm, Adhartal, College of Veterinary Science \& A.H., Nanaji Deshmukh Veterinary Science University, Jabalpur (M.P.). The study was conducted during 21 days pre-partum to 90 days post-partum after the adaptation period of 10 days. The animals were selected on the basis of similarity in body weight, age, parity $\left(1^{\text {st }}\right.$ to $\left.3^{\text {rd }}\right)$ and previous lactation yield. The animals were randomly assigned into two groups as control (CON) and soybean oil (SBO), based on feeding of different feed substances (Table 1).

\section{Feeding regime}

Experimental animals were stall fed and maintained in semi-intensive system of housing. All The experimental animals were fed total mixed ration according to their body weight and production as per ICAR (2013). The chaffed green fodder (berseem / sorghum / maize), and wheat straw were offered ad libitum and concentrate consisting of 18 per cent crude protein and 70 per cent total digestible nutrients was offered at a scale of 1 $\mathrm{kg}$ per $2.0 \mathrm{~kg}$ milk production along with maintenance ration as per routine practices at the farm. Measured quantity of soybean oil (200 ml) was mixed daily in concentrate of supplemented group (SBO) at the time of feeding. Half of the total required quantity of feed was offered daily at morning 5.30 am and rest amount offered in the afternoon $3.00 \mathrm{pm}$. The water was kept available to animals round the clock.

\section{Body Condition Score (BCS) and Body Weight (BW)}

The BCS of buffaloes were evaluated at monthly intervals using visual observation and palpation to the 5 point scale with increments of 0.5.The body weight of each animal was calculated with the help of electronic weighing balance at monthly intervals throughout experimental period.

\section{Feed intake and dry matter (\%)}

Daily intake of concentrate, straw and green fodder was recorded for individual animals. Weighed quantities of concentrate, straw and green fodder were offered to animals and the leftover was collected next day in the morning 
and weighed. The leftover was subtracted from the initial feed supplied to know the actual amount of feed consumed by the animal. The representative samples of concentrate mixture and roughage were taken in moisture cup and kept in hot air oven at $100 \pm 2^{\circ} \mathrm{c}$ for $24 \mathrm{hrs}$ and dry matter was calculated as follows:

Dry matter $(\%)=$

Fresh weight of sample (g)

\section{Milk yield (MY)}

Animals were hand milked twice a day for the first five days and ninety days after calving i.e., at 6 am and $4 \mathrm{pm}$ for recording of colostrum and MY individually. Milk obtained from two times milking was combined together to get the actual MY of the buffaloes for that day. The MY was recorded at fortnightly intervals throughout the experimental period. Peak milk yield was calculated from the milk yield records of the experimental animals.For the conversion of whole milk into 6 per cent FCM yield, the equation derived by Rice (1970) was used. The FCM yield was calculated at fortnightly intervals during 90 days lactation period.

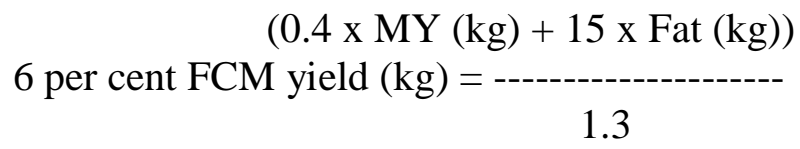

\section{Predicted Lactation Yield (PLY) and Persistency of lactation}

PLY (305 days) was calculated by using ratio estimates of partial lactation of Murrah buffaloes (Thomas and Sastry, 2012). The lactation yield up to 12 weeks was multiplied by the corresponding ratio estimates of 2.8096 to obtain estimates of lactation yield. Persistency of lactation is defined as the milk yield at one test expressed as a percentage of milk yields at an earlier test, adjusted to 30 days interval between tests. Therefore, if two tests are exactly 30 days apart, persistency can be simply calculated as follows:

Milk (kg) at later test

Persistency of lactation $(\%)=------------x 100$

Milk (kg) at earlier test

\section{Milk composition}

The representative milk samples of individual animals were collected from the milking bucket after complete milking of the individual animal and analysed for milk composition (fat, SNF, lactose and protein) at fortnightly intervals throughout the experimental period using Lacto Plus (Ultrasonic auto milk analyzer, Netco Pvt. Ltd.).

\section{Statistical analysis}

Data were analyzed using ANOVA, described by Snedecor and Cochran (1994) and the means showing significant differences in the ANOVA table were compared using the Duncan Multiple Range Test (Steel and Toorie, 1980).

\section{Results and Discussion}

\section{Body Condition Score (BCS)}

The monthly average BCS as in table 2 in lactating Murrah buffaloes at the start of experiment in $\mathrm{CON}$ and $\mathrm{SBO}$ was $2.92 \pm 0.20$ and 2.92 \pm 0.30 , respectively. The final BCS at the end of experiment i.e., 90 days postpartum in $\mathrm{CON}$ and $\mathrm{SBO}$ was $3.42 \pm 0.24$ and $3.60 \pm 0.32$, respectively and the overall average BCS was $3.17 \pm 0.12$ and $3.34 \pm 0.16$ in $\mathrm{CON}$ and SBO, respectively. Statistically, there was no significant difference in the average BCS of lactating Murrah buffaloes between the groups; however the overall BCS 
was numerically higher in SBO followed by CON. The study reveals per cent improvement in body condition from calving to 3 months by 17.12 and 23.29 in $\mathrm{CON}$ and SBO, respectively whereas; overall per cent improvement in SBO was 5.36 in comparison to $\mathrm{CON}$. Continuous increase in BCS was observed in both the groups throughout the study period. Findings further reveal that BCS was positively correlated with DMI.

The non-significant results are in accordance with the findings of Encinias et al., (2001) and Khalil et al., (2012). The continuous increase in BCS in both the groups was supported by the findings of Otto et al., (2016). Numerically higher BCS in SBO in present study corroborate with the findings of Ben-Salem and Bouraoui (2008); Sharma et al., (2016) and Parihar et al., (2018). Under conditions of similar DMI and BW between the groups, the greater energy density of the soybean oil diet allowed a greater intake of energy to support a greater proportion of the milk produced compared with the buffaloes not supplemented. The latter cows had to rely to a greater degree on body reserves for milk production and hence, had numerically lower body condition scores compared to the supplemented group (Boken et al., 2005).

\section{Body Weight (BW)}

The monthly average BW $(\mathrm{kg})$ as in table 2 in lactating Murrah buffaloes at the start of experiment in $\mathrm{CON}$ and $\mathrm{SBO}$ was $524.16 \pm 16.38$ and $549.48 \pm 23.80$, respectively. The final BW of lactating Murrah buffaloes at the end of experiment i.e., 90 days postpartum in CON and SBO was 531.09 \pm 14.83 and $534.48 \pm 21.00$, respectively and the overall average BW was 529.72 \pm 6.95 and $540.75 \pm 10.40$ in $\mathrm{CON}$ and SBO, respectively. Statistically, there was no significant difference in the average $\mathrm{BW}$ of lactating Murrah buffaloes between the groups; however $\mathrm{CON}$ experienced average $\mathrm{BW}$ gain $(\mathrm{kg})$ of 6.93 ; whereas SBO suffered average BW loss $(\mathrm{kg})$ of 15 , throughout the study period. The per cent improvement in BW from calving to 3 months in $\mathrm{CON}$ was 1.32 whereas; per cent decline in SBO was 2.73. The study reveals per cent increase in overall $\mathrm{BW}$ in $\mathrm{SBO}$ by 2.1 in comparison to $\mathrm{CON}$.

The non-significant findings were supported by Encinias et al., (2001); Khalil et al., (2012); Shelke et al., (2012); Altenhofer et al., (2014); Otto et al., (2016) and Parihar et al., (2018). The higher average value of BW in treatment group is in accordance with the results of Kale et al., (2016); Sharma et al., (2016) and Singh et al., (2016). Finding of present study is in accordance with the findings of Suharti et al., (2017) in that there was slight decrease in BW gain in SBO group. This is caused by the utilization of energy which was generated from soybean oil for supporting higher milk production and improving reproductive performance instead for BW gain, which is in agreement with the findings of Funston (2004).

\section{Dry Matter Intake (DMI)}

The fortnightly average daily DMI (kg/animal/day) as in table 3 in lactating Murrah buffaloes at the start of experiment in CON and SBO was 16.80 \pm 0.71 and $16.48 \pm 1.03$, respectively. The final DMI at the end of experiment i.e., 90 days post-partum in $\mathrm{CON}$ and SBO was 21.33 \pm 0.78 and $21.05 \pm 1.06$, respectively and the overall average daily DMI was $19.60 \pm 0.44$ and $19.93 \pm 0.43$ in CON and SBO, respectively. There was no significant difference in the average DMI of lactating Murrah buffaloes between the groups. The overall average daily DMI was numerically higher in SBO followed by CON. The per cent improvement in DMI from calving to 3 months in $\mathrm{CON}$ and $\mathrm{SBO}$ was 26.96 and 27.73, respectively and in 
comparison to $\mathrm{CON}$, overall per cent increase in SBO was 1.68. Continuous increase in the DMI was observed in lactating Murrah buffaloes throughout the study period.

The non-significant findings are in agreement with the findings of Sarwar et al., (2004); AlZahal et al., (2008); Huang et al., (2008); Mele et al., (2008); Sultana et al., (2008); Ye et al., (2009); Tyagi et al., (2010); Dai et al., (2011); Khalil et al., (2012); Mudgal et al., (2012); Shelke et al., (2012); Altenhofer et al., (2014); Khare et al., (2014); Kirovski et al., (2015) and Sharma et al., (2016). Higher numerical value of SBO is similar with the findings of Tyagi et al., (2009); Singh et al., (2016); Suharti et al., (2017) and Parihar et al., (2018). The animals in NEB consume more DMI because of craving for more nutrients to support higher milk production. This was not seen in the present study as animals were not high yielders and the required energy for supporting milk production was met through the diet. This is a possible hypothesis for no significant changes in DMI. Also, short feeding period of 12 weeks or small amount of oil supplementation may be another reason. Further findings reveal that SBO supplemented group had readily accepted the oil supplementation in their diet and it did not alter the palatability of ration, thus, considering it to be the possible cause for increase in DMI.

\section{Daily milk yield}

The fortnightly average daily MY (lit.) as in table 3 in lactating Murrah buffaloes at the start of experiment in $\mathrm{CON}$ and SBO was $6.23 \pm 0.16$ and $7.34 \pm 0.19$, respectively. The average daily MY (lit.) at the end of experiment i.e., 90 days post-partum in CON and SBO was $7.60 \pm 0.12$ and 8.91 \pm 0.13 , respectively. The overall average daily MY (lit.) was found to be significantly $(\mathrm{p}<0.05)$ higher in SBO $(8.97 \pm 0.06)$ than $\mathrm{CON}$
(7.90 \pm 0.06$)$. The overall average daily MY varied significantly between the groups and the per cent increase in daily MY from calving to 3 months period in $\mathrm{CON}$ and $\mathrm{SBO}$ was 22.00 and 21.39, respectively; however SBO showed 13.54 per cent increase in daily MY as compared to $\mathrm{CON}$. The fortnightly average daily MY increased up to $4^{\text {th }}$ fortnight and thereafter decreased gradually.

Similar findings of increase in milk yield by fat supplements were reported by AlZahal et al., (2008); Mele et al., (2008); Sultana et al., (2008); Barley and Baghel (2009); Kathirvelan and Tyagi (2009); Ye et al., (2009); Tyagi et al., (2010); Dai et al., (2011); Khalil et al., (2012); Shelke et al., (2012); Gowda et al., (2013); Madan et al., (2013); Vahora et al., (2013); Otto et al., (2016); Sharma et al., (2016) and Singh et al., (2016). In the present study, gradual decrease in fortnight average daily MY from $5^{\text {th }}$ fortnight onwards was in agreement with the findings of Altenhofer et al., (2014) and Rodrigues (2017). Milk production is generally increased by the inclusion of fat in basal ration probably due to increase in DMI and an improvement in the efficiency of energy utilization. The highest average per cent increase in daily MY was 13.54 in this study than 7.27 and 7.30 reported by AlZahal et al., (2008) and Gowda et al., (2013), respectively which further indicates that pre and post-partum feeding was more effective in eliciting the higher milk production response than feeding alone in early lactation. Less MY in CON as compared to SBO is credited to the non-availability of fat supplements in the ration.

\section{Peak milk yield and persistency of lactation}

The higher average peak milk yield (lit.) was recorded in SBO $(10.48 \pm 0.53)$ than $\mathrm{CON}$ $(10.42 \pm 0.58)$, respectively. There was no significant difference in the average peak milk yield however; the per cent increase in peak 
milk yield in SBO was 0.57 in comparison to CON. The peak milk yield (days) was attained earlier in SBO $(48 \pm 8.61)$ followed by $\mathrm{CON}$ $(51.33 \pm 4.71)$. No significant difference was observed between the groups; however SBO attained peak milk yield earlier by 3.33 days in comparison to $\mathrm{CON}$. Higher peak milk yield (lit.) in SBO corroborate with the findings of Tyagi et al., (2010) and Ranjan et al., (2012). The findings may be attributed to the increased energy density of ration by fat supplementation resulting in higher $\mathrm{MY}$ in comparison to $\mathrm{CON}$. In this study positive correlation between BCS and peak milk yield has also been hypothesized and is similar with the findings of Patel (2016) who reported that for optimum productive and reproductive performance in Murrah buffaloes, animals should be maintained at moderate BCS (3.253.75) during calving.

The persistency of lactation (\%) was found to be higher in SBO (92.28 \pm 3.38$)$ followed by CON (91.21 \pm 2.16$)$. No significant differences were observed between the groups. In comparison to $\mathrm{CON}$, the per cent increase in persistency in SBO was 1.17. The persistency of lactation was monitored for 15 days of lactation after cessation of fat supplementation to the buffaloes and it was observed that SBO supplementation not only increased the MY but the effects persisted even after the supplement was withdrawn and this may be due to better DMI and improved reproductive performances. The findings are in orthodox with the findings of Sampelayo et al., (2004); Tyagi et al., (2009); Tyagi et al., (2010); Ranjan et al., (2012) and Shelke et al., (2012).

\section{Predicted lactation yield (305 days)}

The predicted lactation yield (PLY) (lit./lactation/animal) based on 90 days lactation yield as in table 2 was significantly $(\mathrm{p}<0.05)$ higher in SBO $(2268.83 \pm 95.37)$ followed by CON (1999.95 \pm 85.67$)$. The per cent increase in PLY in SBO was 13.44 in comparison to $\mathrm{CON}$. The possible hypothesis for significantly higher PLY in SBO is credited to higher MY, improved reproductive performances and $\mathrm{BCS}$ in comparison to CON. The present finding is consistent with the study of Moira et al., (1978) who reported that, animals with low BCS i.e., 2 at calving did not achieve their PLY, and those with BCS 2.5 yielded more than their PLY.

\begin{tabular}{|c|c|c|c|c|c|}
\hline \multicolumn{6}{|c|}{ Table.1 Experimental diet were fed as follows } \\
\hline S. No. & Groups & \multicolumn{2}{|c|}{ Number of animals } & \multicolumn{2}{|c|}{ Treatments } \\
\hline 1. & $\mathrm{CON}$ & \multicolumn{2}{|c|}{6} & \multicolumn{2}{|l|}{ Basal diet } \\
\hline 2. & SBO & \multicolumn{2}{|c|}{6} & \multicolumn{2}{|c|}{$\begin{array}{l}\text { Basal diet + Soybean oil supplementation } \\
\text { @ } 200 \mathrm{ml} \text { per animal per day }\end{array}$} \\
\hline \multicolumn{6}{|c|}{$\begin{array}{l}\text { Table.2 Average monthly body condition score (BCS) and body weight (BW; Kg) } \\
\text { (Mean } \pm \text { SE) of lactating Murrah buffaloes in different groups }\end{array}$} \\
\hline \multirow{2}{*}{\multicolumn{2}{|c|}{ Months }} & \multicolumn{2}{|c|}{ BCS } & \multicolumn{2}{|c|}{ BW } \\
\hline & & $\mathrm{CON}$ & SBO & $\mathrm{CON}$ & SBO \\
\hline \multicolumn{2}{|c|}{ Initial } & $2.92 \pm 0.20$ & $2.92 \pm 0.30$ & $524.16 \pm 16.38$ & $549.48 \pm 23.80$ \\
\hline \multicolumn{2}{|c|}{$1^{\text {st }}$} & $3.17 \pm 0.28$ & $3.25 \pm 0.38$ & $530.26 \pm 14.54$ & $539.15 \pm 23.61$ \\
\hline \multicolumn{2}{|c|}{$2^{\text {nd }}$} & $3.17 \pm 0.28$ & $3.60 \pm 0.32$ & $533.39 \pm 13.41$ & $539.88 \pm 20.06$ \\
\hline \multicolumn{2}{|c|}{$3^{\text {rd }}$} & $3.42 \pm 0.24$ & $3.60 \pm 0.32$ & $531.09 \pm 14.83$ & $534.48 \pm 21.00$ \\
\hline \multicolumn{2}{|c|}{ Average } & $3.17 \pm 0.12$ & $3.34 \pm 0.16$ & $529.72 \pm 6.95$ & $540.75 \pm 10.40$ \\
\hline
\end{tabular}




\begin{tabular}{|c|c|c|c|c|c|c|}
\hline \multirow{2}{*}{ Fort. } & \multicolumn{2}{|c|}{ DMI } & \multicolumn{2}{|c|}{ Daily milk yield } & \multicolumn{2}{|c|}{ Milk fat } \\
\hline & CON & SBO & CON & SBO & CON & SBO \\
\hline 1 & $16.80 \pm 0.71$ & $16.48 \pm 1.03$ & $6.23 \pm 0.17$ & $7.34 \pm 0.18$ & $6.19 \pm 0.02$ & $6.99 \pm 0.02$ \\
\hline 2 & $18.07 \pm 0.57$ & $19.81 \pm 0.80$ & $8.10 \pm 0.10$ & $8.90 \pm 0.12$ & $6.70 \pm 0.04$ & $7.18 \pm 0.02$ \\
\hline 3 & $20.32 \pm 1.25$ & $20.50 \pm 0.85$ & $8.51 \pm 0.11$ & $9.54 \pm 0.08$ & $6.96 \pm 0.01$ & $7.36 \pm 0.02$ \\
\hline 4 & $20.37 \pm 1.26$ & $20.42 \pm 0.97$ & $8.81 \pm 0.13$ & $9.81 \pm 0.04$ & $7.10 \pm 0.01$ & $7.43 \pm 0.06$ \\
\hline 5 & $20.90 \pm 0.99$ & $20.43 \pm 0.88$ & $8.20 \pm 0.13$ & $9.32 \pm 0.10$ & $7.19 \pm 0.01$ & $7.67 \pm 0.01$ \\
\hline 6 & $21.33 \pm 0.78$ & $21.05 \pm 1.06$ & $7.60 \pm 0.12$ & $8.91 \pm 0.13$ & $7.20 \pm 0.01$ & $7.69 \pm 0.01$ \\
\hline Avg. & $19.60 \pm 0.44$ & $19.93 \pm 0.43$ & $7.90^{\mathrm{a}} \pm 0.06$ & $8.97^{b} \pm 0.06$ & $6.89^{\mathrm{a}} \pm 0.01$ & $7.39^{b} \pm 0.01$ \\
\hline
\end{tabular}

Table.4 Fortnightly average milk SNF, protein, lactose (\%) and 6\% FCM yield in lactating Murrah buffaloes (Mean \pm SE) in different groups

\begin{tabular}{|c|c|c|c|c|c|c|c|c|}
\hline \multirow[t]{2}{*}{ Fort. } & \multicolumn{2}{|c|}{ SNF } & \multicolumn{2}{|c|}{ Protein } & \multicolumn{2}{|c|}{ Lactose } & \multicolumn{2}{|c|}{$6 \%$ FCM yield } \\
\hline & CON & SBO & CON & SBO & CON & SBO & CON & SBO \\
\hline 1 & $10.21 \pm 0.13$ & $9.76 \pm 0.32$ & $3.99 \pm 0.05$ & $3.83 \pm 0.11$ & $5.42 \pm 0.08$ & $5.13 \pm 0.17$ & $6.95 \pm 0.18$ & $8.87 \pm 0.23$ \\
\hline 2 & $9.65 \pm 0.30$ & $9.96 \pm 0.25$ & $3.75 \pm 0.12$ & $3.89 \pm 0.10$ & $5.10 \pm 0.17$ & $5.27 \pm 0.14$ & $9.49 \pm 0.11$ & $10.92 \pm 0.15$ \\
\hline 3 & $9.81 \pm 0.19$ & $9.24 \pm 0.17$ & $3.83 \pm 0.07$ & $3.61 \pm 0.06$ & $5.18 \pm 0.10$ & $4.83 \pm 0.10$ & $10.23 \pm 0.15$ & $11.93 \pm 0.14$ \\
\hline 4 & $10.09 \pm 0.19$ & $9.17 \pm 0.37$ & $3.94 \pm 0.07$ & $3.57 \pm 0.13$ & $5.35 \pm 0.09$ & $4.80 \pm 0.20$ & $10.73 \pm 0.16$ & $12.29 \pm 0.10$ \\
\hline 5 & $9.73 \pm 0.17$ & $9.62 \pm 0.22$ & $3.80 \pm 0.06$ & $3.74 \pm 0.07$ & $5.13 \pm 0.08$ & $5.08 \pm 0.09$ & $10.08 \pm 0.15$ & $11.98 \pm 0.15$ \\
\hline 6 & $9.55 \pm 0.21$ & $9.49 \pm 0.16$ & $3.72 \pm 0.08$ & $3.71 \pm 0.05$ & $5.03 \pm 0.10$ & $4.98 \pm 0.06$ & $9.34 \pm 0.14$ & $11.48 \pm 0.17$ \\
\hline Avg. & $9.84 \pm 0.09$ & $9.54 \pm 0.10$ & $3.82 \pm 0.03$ & $3.72 \pm 0.04$ & $5.18 \pm 0.05$ & $5.01 \pm 0.05$ & $9.47^{\mathrm{a}} \pm 0.08$ & $11.25^{b} \pm 0.08$ \\
\hline
\end{tabular}

Milk composition

Fat

The fortnightly average milk fat per cent as in table 3 in lactating Murrah buffaloes at the start of experiment were $6.19 \pm 0.02$ and $6.99 \pm 0.02$ in $\mathrm{CON}$ and $\mathrm{SBO}$, respectively. The fortnightly average fat per cent at the end of experiment i.e., 90 days post-partum in CON and SBO was 7.20 \pm 0.01 and $7.69 \pm 0.01$, respectively. The overall average fat per cent varied significantly $(p<0.05)$ between the groups and the values were higher in SBO (7.39 \pm 0.01$)$ than CON $(6.89 \pm 0.01)$. The average fat per cent in milk has increased throughout the study period in all the groups.
The per cent increase in milk fat from calving to 3 months period in $\mathrm{CON}$ and $\mathrm{SBO}$ was 16.32 and 10.01, respectively; however milk fat per cent was significantly higher in SBO by 7.25 per cent in comparison to $\mathrm{CON}$. Further, results reveal higher fat yield $(\mathrm{kg})$ in SBO (0.66) followed by CON (0.54).

The higher fat per cent in milk of supplemented group is in orthodox with the findings of Mele et al., (2008); Barley and Baghel (2009); Shelke et al., (2012); Madan et al., (2013); Vahora et al., (2013); Kirovski et al., (2015); Moncada-Lainez and LiangChou (2016); Otto et al., (2016); Sharma et al., (2016) and Thul et al., (2017). The increase in fat per cent in milk of 
supplemented group may be attributed to the availability of more fatty acids for absorption in intestine and these fatty acids are directly incorporated in milk fat after absorption from intestine, leading to increase in milk fat, which is in confirmation with the findings of Shelke et al., (2012).

\section{Solid Not Fat (SNF)}

The fortnightly average milk SNF per cent as in table 4 in lactating Murrah buffaloes at the start of experiment was $10.21 \pm 0.13$ and $9.76 \pm 0.32$ in $\mathrm{CON}$ and $\mathrm{SBO}$, respectively. The fortnightly average SNF per cent at the end of experiment i.e., 90 days post-partum was $9.55 \pm 0.21$ and $9.49 \pm 0.16$ in $\mathrm{CON}$ and $\mathrm{SBO}$, respectively. The overall average SNF per cent was $9.84 \pm 0.09$ and $9.54 \pm 0.10$ in CON and SBO, respectively. There was no significant difference in overall average SNF per cent in milk of lactating Murrah buffaloes between the groups; however the numerical values were higher in CON followed by SBO.

\section{Protein}

The fortnightly average milk protein per cent as in table 4 in lactating Murrah buffaloes at the start of experiment was $3.99 \pm 0.05$ and $3.83 \pm 0.11$ in $\mathrm{CON}$ and $\mathrm{SBO}$, respectively. The fortnightly average protein per cent at the end of experiment i.e., 90 days post-partum was $3.72 \pm 0.08$ and $3.71 \pm 0.05$ in $\mathrm{CON}$ and SBO, respectively. There was no significant difference in the overall average protein per cent between the groups and the values were numerically higher in CON $(3.82 \pm 0.03)$ followed by SBO (3.72 \pm 0.04$)$.

The reduction in milk protein per cent in SBO is related to the dilution of milk protein as higher milk volume synthesized is not synchronous with the uptake of amino acids by the mammary gland (DePeters and Cantt, 1992). Further dietary fat decreases milk protein synthesis by inducing insulin resistance (Palmquist and Moser, 1981) or it could be a result of an adverse effect on microbial fermentation and subsequent decline in microbial protein reaching the small intestine (Jenkins, 1993).

\section{Lactose}

The fortnightly average milk lactose per cent as in table 4 in lactating Murrah buffaloes at the start of experiment was 5.42 \pm 0.08 and $5.13 \pm 0.17$ in CON and SBO, respectively. The fortnightly average lactose per cent at the end of experiment i.e., 90 days post-partum was $5.03 \pm 0.10$ and $4.98 \pm 0.06$ in $\mathrm{CON}$ and SBO, respectively. There was no significant difference in the overall average lactose per cent between the groups and the values were numerically higher in CON $(5.18 \pm 0.05)$ followed by SBO (5.01 \pm 0.05$)$.

The non-significant findings in SNF, protein and lactose per cent in milk is in confirmation with the findings of Sultana et al., (2008); Kathirvelan and Tyagi (2009); Dai et al., (2011); Altenhofer et al., (2014); Kirovski et al., (2015); Moncada-Lainez and Liang-Chou (2016) and Sharma et al., (2016). The less dose of supplementation of oil may be a reason for non-significant results in per cent SNF, protein and lactose in milk.

\section{Fat corrected milk (FCM) yield}

The fortnightly average 6 per cent FCM yield (kg) as in table 4 in lactating Murrah buffaloes at the start of experiment in $\mathrm{CON}$ and SBO was $6.95 \pm 0.18$ and $8.87 \pm 0.23$, respectively. The average 6 per cent FCM yield $(\mathrm{kg})$ at the end of experiment i.e., 90 days post-partum in $\mathrm{CON}$ and SBO was $9.34 \pm 0.14$ and $11.48 \pm 0.17$, respectively. The overall average 6 per cent FCM yield $(\mathrm{kg})$ varied significantly between the groups and the values were statistically higher in SBO 
(11.25 \pm 0.08$)$ followed by CON $(9.47 \pm 0.08)$. The per cent increase in FCM yield from calving to 3 months period in $\mathrm{CON}$ and $\mathrm{SBO}$ was 34.39 and 29.42; however SBO showed 18.80 per cent increase in FCM yield as compared to CON. The fortnightly average 6 per cent FCM yield $(\mathrm{kg})$ increased up to $4^{\text {th }}$ fortnight and thereafter decreased gradually.

The present findings are consistent with the findings of Sultana et al., (2008); Vahora et al., (2013) and Sharma et al., (2016). The increase in 6 per cent FCM yield is credited to the higher average daily MY and milk fat per cent in SBO over CON.

The present findings indicate that there were no negative effects of supplementation of SBO on BCS, body weight, dry matter intake, peak milk yield and persistency of lactation throughout the study period as compared to $\mathrm{CON}$ and the numerical values were higher in SBO than CON. On the other hand, SBO significantly $(\mathrm{p}<0.05)$ improved average daily milk yield, 6 per cent FCM yield, milk fat per cent and predicted lactation yield as compared to CON. There were no effects on milk components (SNF, protein and lactose) between the groups. These results suggest that SBO supplementation is a better alternative for solving negative energy balance in lactating Murrah buffaloes and it could be recommended during transition period and early lactation to get maximum benefits to the farmers by improving production performances.

\section{References}

Altenhofer, C., M. Spornraft, H. Kienberger, M. Rychlik, J. Herrmann, H.H.D. Meyer and Viturro, E. 2014. Effects of rapeseed and soybean oil dietary supplementation on bovine fat metabolism, fatty acid composition and cholesterol levels in milk. Journal of Dairy Research, 81: 120-128.

AlZahal, O., N.E. Odongo, T. Mutsvangwa, M.M. Or-Rashid, T.F. Duffield, R. Bagg, P. Dick,G. Vessieand McBride, B.W. 2008. Effects of monensin and dietary soybean oil on milk fat percentage and milk fatty acid profile in lactating dairy cows. Journal of Dairy Science, 91(3): 1166-1174.

Barley, G.G. and Baghel, R.P.S. 2009. Effect of bypass fat supplementation on milk yield, fat content and serum triglyceride levels of Murrah buffaloes. Buffalo Bulletin, 28(4): 173-175.

Ben-Salem, M. and Bouraoui, R. 2008. Effects of calcium salts of palm fatty acids and protected methionine supplementation on milk production and composition and reproductive performances of early lactation dairy cows. International Journal of Dairy Science, 3: 187-193.

Boken, S.L., C.R. Staples, L.E. Sollenberger, T.C. Jenkins and Thatcher, W.W. 2005. Effect of grazing and fat supplementation on production and reproduction of Holstein cows. Journal of Dairy Science, 88(12): 4258-4272.

Dai, X.J., C. Wang and Zhu, Q. 2011. Milk performance of dairy cows supplemented with rapeseed oil, peanut oil and sunflower seed oil. Czech Journal of Animal Science, 56(4): 181191.

DePeters, E.J. and Cant, J.P. 1992. Nutritional factors influencing the nitrogen composition of bovine milk: A review. Journal of Dairy Science, 75: 20432070.

Encinias, H.B., A.M. Encinias, J.J. Spickler, B. Kreft, M.L. Bauer and Lardy, G.P. 2001. Effects of prepartum high linoleic safflower seed supplementation for gestating cows on performance of cows 
and calves. In: NDSU Beef Cattle Report, 2001, pp 7-10.

Funston, R.N. 2004. Fat supplementation and reproduction in beef females. Journal of Animal Science, 82: E154-E161.

Gowda, N.K.S., A. Manegar, A. Raghavendra, S. Verma, G. Maya, D.T. Pal, K.P. Sureshand Sampath, K.T. 2013. Effect of protected fat supplementation to high yielding dairy cows in field condition. Animal Nutrition and Feed Technology, 13: 125-130.

Huang, Y., J.P. Schoonmaker, B.J. Bradford and Beitz, D.C. 2008. Response of milk fatty acid composition to dietary supplementation of soy oil, conjugated linoleic acid or both. Journal of Dairy Science, 91(1): 260-270.

ICAR. 2013. Nutrient requirements of cattle and buffalo. Indian Council of Agriculture Research, New Delhi, India.

Jenkins, T.C. 1993. Lipid metabolism in the rumen. Journal of Dairy Science, 76: 3851-3863.

Kale, V., S. Kumar, N. Kewalramani, V. Mani,N. Tyagi and Tyagi, A.K. 2016. Comparative study of mustard, soybean and rice bran oil: Effects on nutrient utilization, growth performance and blood metabolites in growing Murrah buffalo (Bubalus bubalis) heifers. Animal Nutrition and Feed Technology, 16(3): 383-392.

Kathirvelan, C. and Tyagi, A.K. 2009. Conjugated linoleic acid content of milk from buffaloes fed a mustard oil based diet. International Journal of Dairy Technology, 62(2): 141-146.

Khalil, W.A., M.A. El-Harairyand Abul-Atta, A.A. 2012. Impact of dietary protected fat (Magnapac) on productive and reproductive performances of lactating Holstein cows. Journal of Animal and Poultry Production, 3(10): 437-450.
Khare, A., R.P.S. Baghel, R.S. Gupta, S. Nayak, V. Khare, A. Patil, R. Sharma, R. Tomar and Singh, V.P. 2014. Milk production of indigenous cattle fed supplements of mustard oil cake or azolla meal (Azolla filiculoides). Livestock Research for Rural Development, 26(4): 1-10.

Kirovski, D., B. Blond, M. Katic, R. Markovic and Sefer, D. 2015. Milk yield and composition, body condition, rumen characteristics and blood metabolites of dairy cows fed diet supplemented with palm oil. Chemical and biological technologies in agriculture, 2: 1-5.

Madan, J., N. Saxena, C. Mohan, R. Kumar, K. Kumar and Lal, D. 2013. Field study on protected fat feeding during summer season on milk yield and milk composition in buffaloes. Haryana Veterinary, 52: 93-95.

Maiga, H.A. and Schingoethe, D.J. 1997. Optimizing the utilization of animal fat and ruminal bypass proteins in the diets of lactating dairy cows.Journal of Dairy Science, 80: 343-352.

Maiga, H.A., D.J. Schingoethe and Ludens, F.C. 1995. Evaluation of diets containing supplemental fat with different sources of carbohydrates for lactating dairy cows. Journal of Dairy Science, 78(5): 1122-1130.

Mele, M., A. Serra, A. Buccioni, G. Conte, A. Pollicardo and Secchiari, P. 2008. Effect of soybean oil supplementation on milk fatty acid composition from Saanen goats fed diets with different forage: concentrate ratios. Italian Journal of Animal Science, 7: 297-311.

Moira, J., A. Frood and Croxton, D. 1978. The use of condition-scoring in dairy cows and its relationship with milk yield and live weight. Journal of Animal Production, 27(3): 285-291. 
Moncada-Lainez, M. and Hsia, L.C. 2016. Effect of tea leaf and soybean oil supplementation on milk composition of dairy cows. Journal of Research in Agriculture and Animal Science, 3(11): 1-6.

Mudgal, V., R.P.S. Baghel, A. Ganie and Srivastava, S. 2012. Effect of feeding bypass fat on intake and production performance of lactating crossbred cows. Indian Journal of Animal Research, 46: 103-104.

Otto, J.R., P. Nish, R.O. Balogun, M.J. Freeman, B.S. Malau-Aduli, P.A. Lane and Malau-Aduli, A.E.O. 2016. Effect of dietary supplementation of pasturebased primiparous Holstein Friesian cows with degummed crude canola oil on body condition score, live weight, milk yield and composition. Journal of Applied Animal Research, 44(1): 194200.

Palmquist, D.L. and Moser, E.A. 1981. Dietary fat effects on blood insulin, glucose utilization and milk protein of lactating cows.Journal of Dairy Science,64: 1664.

Parihar, S., G.P. Lakhani, R.P.S. Baghel, S. Ghosh and Roy, B. 2018. Changes in productive and reproductive performance of indigenous lactating cattle fed on mustard oil and molasses supplementation. International Journal of Livestock Research, 8(1): 166-170.

Patel, M. 2016. Body condition score and its impact on performance of Murrah buffaloes. M.V.Sc. thesis (Department of Livestock Production and Management), Nanaji Deshmukh Veterinary Science University, Jabalpur, M.P., India.

Ranjan, A., B. Sahoo, V.K. Singh, S. Srivastava, S.P. Singh and Pattanaik, A.K. 2012. Effect of bypass fat supplementation on productive performance and blood biochemical profile in lactating Murrah (Bubalus bubalis) buffaloes. Tropical Animal Health and Production, 44: 1615-1621.

Rice, V.A. 1970. Breeding and improvement of farm animals. McGraw Hill Book Co., Bombay, India.

Rodrigues, J.P.P. 2017. Soybean oil supplementation for cattle: Effects on in vitro digestion, dairy cattle performance, and milk fat composition. D.Sc. thesis, Federal University of Vicosa, Vicosa, Minas Gerais, Brazil.

Sampelayo, M.R.S., J.J.M. Alonso, L. Perez, F.G. Extremera and Boza, J. 2004. Dietary supplements for lactating goats by polyunsaturated fatty acid rich protected fat.Effects after supplement withdrawal. Journal of Dairy Science, 87: 1796-1802.

Sarwar, M., M.A. Khan and Nisa, M. 2004. Influence of ruminally protected fat and urea treated corncobs ensiled with or without corn steep liquor on nutrient intake, digestibility, milk yield and its composition in Nili-Ravi buffaloes. Asian-Australasian Journal of Animal Science, 17: 86-93.

Sharma, S., M. Singh, A.K. Roy and Thakur, S. 2016. Effect of pre-partum prilled fat supplementation on feed intake, energy balance and milk production in Murrah buffaloes. Veterinary World, 9(3): 256259.

Shelke, S.K., S.S. Thakur and Amrutkar, S.A. 2012. Effect of feeding protected fat and proteins on milk production, composition and nutrient utilization in Murrah buffaloes (Bubalus bubalis). Animal Feed Science and Technology, 171: 98-107.

Singh, M., G. Yadav, A.K. Roy and Thakur, S. 2016. Productive performance and metabolic hormonal profile in cows supplemented with prilled fat. Indian Journal of Traditional Knowledge, 15(2): 292-296. 
Snedecor, G.W. and Cochran, W.G. 1994. Statistical Methods, $7^{\text {th }}$ Edn., Oxford \& IBH Publishing Co., New Delhi, India.

Steel, R.G.D. and Torrie, J.H. 1980. Principles and procedures of statistics. A biometrical approach, $2^{\text {nd }}$ Edn., McGraw Hill Book Co., New York, USA.

Suharti, S., L. Khotijah, A.R. Nasution, D.A. Warmadewi, G.L.O. Cakra, C. Arman and Wiryawan, K.G. 2017. Productive and reproductive performances and blood profile of Bali cows supplemented with calcium soapsoybean oil. Pakistan Journal of Nutrition, 16(11): 882-887.

Sultana, H., T. Ishida, T. Shintaku, S. Kanda and Itabashi, H. 2008. Effect of feeding Ca-salts of fatty acids from soybean oil and linseed oil on c9, t11-CLA production in ruminal fluid and milk of Holstein dairy cows. Asian-Australasian Journal of Animal Sciences, 21(9): 1262-1270.

Thakur, S.S. and Shelke, S.K. 2010. Effect of supplementing bypass fat prepared from soybean acid oil on milk yield and nutrient utilization in Murrah buffaloes. Indian Journal of Animal Science, 80(4): 354-357.

Thomas, C.K. and Sastry, N.S.R. 2012. Dairy

Bovine Production, $2^{\text {nd }}$ rev. Edn., Kalyani Publishers, New Delhi, India.
Thul, M.R., P.S. Oberoi, A. Kumaresan, D.S. Gonge, P. Bharti, K.P. Japheth and Chandrasekar, T. 2017. Effect of mustard oil supplementation during transition period on milk composition and calf birth weight in Murrah buffaloes. International Journal of Livestock Research, 7(7): 132-139.

Tyagi, N., S.S. Thakur and Shelke, S.K. 2009. Effect of feeding bypass fat supplement on milk yield, composition and nutrient utilization in crossbred cows. Indian Journal of Animal Nutrition, 26: 1-8.

Tyagi, N., S.S. Thakur and Shelke, S.K. 2010. Effect of bypass fat supplementation on productive and reproductive performance in crossbred cows. Tropical Animal Health and Production, 42: 1749-1755.

Vahora, S.G., S. Parnerkar and Kore, K.B. 2013. Productive efficiency of lactating buffaloes fed bypass fat under field conditions: Effect on milk yield, milk composition, body weight and economics. Iranian Journal of Applied Animal Science, 3(1): 53-58.

Ye, J.A., C. Wang, H.F. Wang, H.W. Ye, B.X. Wang, H.Y. Liu, Y.M. Wang, Z.Q. Yang and Liu, J.X. 2009. Milk production and fatty acid profile of dairy cows supplemented with flaxseed oil, soybean oil, or extruded soybeans. Acta Agriculturae Scandinavica, 59(2): 121-129.

\section{How to cite this article:}

Aayush Yadav, G.P. Lakhani, Biswajit Roy, Bhavna Aharwal, Sudipta Ghosh and Baghel, R.P.S. 2018. Production Performances of Lactating Murrah Buffaloes Supplemented with Soybean Oil. Int.J.Curr.Microbiol.App.Sci. 7(10): 3332-3343.

doi: https://doi.org/10.20546/ijcmas.2018.710.386 